\title{
Üniversite Öğrencilerinin Sosyal Medya Kullanım Alışkanlıkları: Necmettin Erbakan Üniversitesi Örneği
}

\author{
Mustafa İnce ${ }^{a^{*}}$, Mevlut Can Koçak ${ }^{b}$ \\ a,b Karabük Üniversitesi, Safranbolu Meslek Yüksekokulu, Karabük.
}

\begin{abstract}
$\ddot{O} z$
Internetle birlikte bireysel, ticari, sosyal ve toplumsal hayatımızda köklü değişiklikler olmuştur. Özellikle bireysel olarak internetin kullanımı, insanları sıradan yaşam tarzının ötesine taşımıştır. Sosyal medya olarak adlandırılan ve milyonlarca kullanıcısı bulunan sosyal ağlar vasıtasıyla insanlar, neredeyse yaşam alanlarının tümünü dijital ortama taşımaktadır. Bu yönüyle sosyal medya, insan hayatında giderek daha fazla yer tutmaya başlamıştır. Sosyal medyanın kendine özgü çekiciliği, çeşitli konularda bilgi paylaşımı, interaktif olması, etkileşim sağlaması, bireysel düşünceleri yayınlama imkânı sunması gibi özellikleri sayesinde, bilhassa gençler sosyal medyaya büyük ilgi göstermektedir. Bu araştırma üniversite öğrencileri özelinde, gençlerin sosyal medya kullanım alışkanliklarını ortaya koymak amacıyla yürü̈tülmüştür. Saha araştırması yönteminin kullanıldığı bu çalışmada veriler, 520 katılımcıdan yüz yüze anket tekniğiyle toplanmıştır. Araştırma sonuçlarına göre; kadınların bir oturumda sosyal medya kullanım süresi, erkeklere göre daha yüksektir. Üniversite öğrencilerinin sosyal medya kullanım süresi arttıkça; sosyal medyaya güven ve bağımlllık düzeyinde de bir artış yaşanmaktadır. Yine araştırmada eğlenme ve rahatlama isteği, arkadaşlarla iletişimde bulunmak ve çeşitli konularda bilgi sahibi olma isteği sosyal medya kullanıma yönelten nedenle arasında ilk sıralarda yer almaktadır.
\end{abstract}

Anahtar Kelimeler: Sosyal medya, üniversite öğrencileri, internet kullanımı.

\section{Social Media Habits of University Students: a Case of Necmettin Erbakan University}

\begin{abstract}
With the internet, there have been radical changes in our individual, commercial, social and society life. Especially the usage of the internet as an individual has led people beyond ordinary lifestyles. Through social networks, which are called social media and have millions of users, people almost move their living spaces to the digital space entirely. In this sense, social media has begun to take place more and more in human life. Especially young people show great interest in social media thanks to their unique attraction of social media, sharing of information on various topics, being interactive, providing interactivity and publishing individual thoughts. This research has been conducted in order to reveal the social media usage habits of young people, at example of university students. The field survey method was used in this study and data was collected by face to face survey technique from 520 participants. According to results of research; the duration of women's social media usage at one session is higher than that of men. As the duration of social media usage of university students increases; there is also an increase in the level of trust and dependence on social media. Wish of pleasure and relaxation, communication with friends and wish of having information in various subjects are in the first place among the reasons to direct usage of social media.
\end{abstract}

Keywords: Social media, university students, usage of internet 


\section{GíRiş}

İletişim alanında, tarihsel süreç içerisinde devrim niteliğinde birçok gelişme yaşanmıştır. Bunlar arasında yazının bulunması, matbaanın icadı, elektronik yayıncılığa geçiş sayılabilir. Bu devrimlerin hepsi insan yaşamını farklı şekillerde etkilemiştir. İnternette bu devrimlerden birisidir. İnternet, gerçekten de iletişim alanında adeta bir devrim yaratmıştır. İnternet sayesinde insanlar internet üzerinden her yere bilgi gönderme ve bilgi alma imkânına kavuşmuştur. (Neumann ve ark, 2005: 473). Hızı, erişilebilirliği, ucuzluğu, kolaylığı vb. birçok açıdan bireylerin yaşamını ciddi şekilde kolaylaştırmıştır. Günümüzde yönetimler, kurumlar, ticari kuruluşlar internetin sağladığı imkânlardan yararlanmaktadırlar. İnternet bireyler için de, başta bilgi edinmek ve veri paylaşımı olmak üzere, bankacılıktan, alışverişe, ulaşımdan, sağlık hizmetlerine erişime kadar pek çok alanda kolaylık sağlamaktadır.

Bireyler interneti sadece günlük işlerini kolaylaştıracak bazı işlemleri yapmak için kullanmamıştır. Aynı zamanda daha çok eğlenme ve hoş zaman geçirme maksatlı kullanmaya başlamışlardır. Üstelik geldiğimiz noktada sosyal medya ya da sosyal mecra olarak adlandırılan bu ortamlarda ciddi vakitler harcanmaya başlanmıştır.

Sosyal medya ortaya çıtığından buyana insanların ilgisini çekmektedir. Özellikle internet üzerinden bağlantı sağlanan Facebook, Twitter, MySpace, Bebo ve Instagram gibi sosyal paylaşım ağlarına ilgi her gecen gün artarken bu ağlara yenileri de eklenmektedir (Body ve Ellison, 2007: 210-213). Kullanıcılar bu sosyal paylaşım ağları sayesinde kendi sayfalarını oluşturabilme imkânına kavuşmuştur (Al-Deen ve Hendricks, 2012: 5). Bu ağları aracılığıyla kullanıcılar yaş, yaşadı̆̆ı yer, ilgi alanları vb. hakkında bilgiler verebilmekte bunun yanında fotoğraflar ve videolar yükleyerek ve paylaşarak birbirleriyle iletişim kurabilmektedir (Body ve Ellison, 2007: 210-213). Ayrıca sosyal medya üzerinden gerçekleştirilen birçok etkinlik de sosyal medya sayesinde geniş kitlelere ulaşmaktadır (Ryon, 2011:6).

Gençler arasında internet kullanımın önemli bir kısmını sosyal medya oluşturmaktadır (Obee, 2012:8). "İnternet kullanımı artıkça sosyal medya kullanımında da bir artış görülmektedir. Sosyal medyanın kullanıcılar arasında sadece iletişim sağlamaması, bunun yanında oyun oynama, bilgi edinme, arama yapma gibi birçok alanda kullanılması sosyal medyaya olan ilgiyi arttırmaktadır; çünkü insanlar sosyal paylaşım ağlarına sahip olarak pek çok uygulamaya erişebilmektedir." (Tektaş 2014: 852).

Giderek yaygınlaşan, çeşitlenen ve kullanıcı sayısı artan bu mecra / mecralar hakkında insanların düşünce, tutum ve davranışların da önem kazanmaktadır. Necmettin Erbakan Üniversitesi'nin çeşitli fakülte ve meslek yüksekokullarında eğitim gören öğrenciler üzerinde yürütülen bu çalışma, üniversite öğrencilerin sosyal medya kullanım maksatlarını, sosyal medyaya duyulan güven ve bağımlılık düzeylerini ortaya koymayı amaçlamaktadır. 


\section{SOSYAL MEDYA KAVRAMI}

Hayatımıza internetle birlikte giren sosyal medya, tanım ve kavram olarak da tartışılmaktadır. Hatta tartışmanın bizzat isminde başladığını da belirtmek gerekir. Sosyal medya bir medya mıdır? Yoksa insanların bilgi, duygu ve düşüncelerini paylaştıkları bir çoklu ortam mıdır? “İlk olarak sosyolog Stanley Milgram (1967) tarafından ortaya atılan küçük dünya (small world) fenomeni, insanların internet ortamında bağlantılar oluşturarak iletişime geçmeye başlamalarıyla güçlenmiştir" (Onant ve Alikılıç, 2008, Aktaran: Özdemir, 2014: 59).

Sosyal medyayı, çeşitli mecralarda, kullanıcıların bilgi, duygu, düşünce, tecrübe, ilgi ve başka diğer verileri, sesli ve görüntülü olarak, tanıdığı ya da tanımadığı kişilerle paylaşması olarak da tanımlayabiliriz.

"Sosyal medya en basit ifadeyle internet kullanıcılarının birbirleriyle çevrimiçi iletişim kurmalarına olanak veren, içerik paylaşımı ve kişisel yorumlar gibi aktivitelere dayalı sosyal ağ siteleri olarak tanımlanabilir" (Kirtiş ve Karahan, 2011, Aktaran; Özdemir, 2014: 59).

Sosyal medya günümüzde önemli iletişim kanallarından birisidir. Sosyal medya sayesinde insanlar birbiriyle iletişim kurabilmenin yanında birçok veri ve bilgiyi de paylaşabilmektedir. Sosyal medya ile birlikte insanlar artık sadece seyirci değildir, kullanıcılar artık sosyal medya üzerinden kendi içeriklerini oluşturabilmekte ve bu içeriklerini başkalarıyla paylaşabilmektedirler. İnsanların sosyal medya sayesinde içeriğe müdahil olması onu geleneksel medyadan ayıran belki de en önemli özelliği olmuştur. Bu özellik onu geleneksek medya karşısında avantajlı bir duruma getirmektedir.

Sosyal medya ortamında kişiler kendilerini sunma (ifade etme) imkânı bulmasının yanında diğer insanlarla tanışma ya da önceden tanıdıkları kişiler ile iletişim kurabilme imkânına sahiptir (Çalışır, 2015: 119). Sosyal medya aynı zamanda diğer kişilerle ilişkileri geliştirip, devamlı kılmayı da olanaklı hale getirmektedir (Balcı ve Koçak, 2017: 44).

Sosyal ağlar her geçen gün toplumun önemli bir kısmı üzerinde önemli bir değere sahip olmaya başlamıştır. İnsanlar evden, okuldan ve iş yerlerinden bilgisayar veya cep telefonu kullanarak sosyal paylaşım ağlarında zaman geçirmeye başlamıştır (Lüsted, 2011: 6-7). Özellikle akıllı telefonların son yıllarda iyice kullanımının artmasıyla insanlar her ortamda internete erişebilir duruma gelmiştir (Englander ve ark, 2010: 86). Bu da (paralel olarak) sosyal medyaya her ortamda girme imkânına erişilmesini sağlanmıştır (Lüsted, 2011: 6-7).

“Sanal ortam kullanıcıları sosyal medyaya günümüzde büyük ilgi göstermektedir. Sosyal medya farklı kültürler ve farklı kesimlerden insanların sosyal taleplerini karşılamaktadır. Sosyal medya ortamı dediğimiz yer sürekli kendini yenileyen, çoklu kullanıma açık olan ve kullanıcıların sanal paylaşımına olanak taniyan bir yerdir. Sosyal medya üzerinden kullanıcılar fikirlerini belirtmekte, bu fikirler üzerinden yer ve zaman sorunu olmadan tartışma yapabilmektedirler." (Vural 
ve Bat, 2010: 3349). Sosyal medya denilince akla sadece Facebook, Twitter gelmemelidir. Youtube başta olmak üzere forumlar, bloglar hepsi birer sosyal medya örneğidir (Fouts, 2009: 6). Özellikle bakıldığında çok kısa sürede pek çok sosyal paylaşım ağları ortaya çıkmıştır hala da çıkmaya devam etmektedir (Van Dijck, 2013: 7).

\section{SOSYAL MEDYA KULLANIMINA ILIŞKİN BAZI ARAŞTIRMA BULGULARI}

Giderek yaygınlaşan, durumu tartışılan ve insanlar üzerindeki etkisi önem kazanan sosyal medyanın kullanımına yönelik dünyada ve ülkemizde çalışmalar yapılmaktadır. Bunlardan biri Hazar (2011: 163-166) tarafından Gazi Üniversitesinde 248 kişi üzerinde gerçekleştirilen araştırmadır. Araştırmada, katılımcıların yüzde 47,2'si, yani yaklaşık yarısı sosyal medyayı en çok bilgi edinmek için kullandığı sonucuna varılırken bunu yüzde 23 ile haberleşme izlemektedir.

Vural ve Bat (2010:3363) tarafından Ege Üniversitesinde iletişim fakültesinde eğitim gören 319 öğrenci üzerinde bir araştırma gerçekleştirmiştir. Sosyal medya kullanımına yönelik bu araştırmanın sonucunda, katılımcıların yüzde 31'inin sosyal medyayı zaman geçirmek için, yüzde 18,5'inin çevrimiçi sohbet etmek için, yüzde 13,2 'sinin ise profilini güncellemek için kullandıkları tespit edilmiştir.

Tektaş (2014: 864) tarafından Marmara Üniversitesi Teknik Bilimler Meslek Yüksekokulunda 221 üniversite öğrencisi üzerinde gerçekleştirilen araştırmada ise, sosyal paylaşım sitelerinde, kadın öğrencilerin erkek öğrencilere göre daha fazla vakit geçirdikleri tespit edilmiştir.

Küçükali (2016: 538-543) tarafından Erzurum'da Atatürk Üniversitesinde 215 üniversite öğrencisi üzerinde gerçekleştirdiği araştırmada, katılımcıların çok büyük bir kısmının sosyal medyayı eğlenmek ve rahatlamak için kullandığı sonucuna ulaşmıştır. Araştırma sorusuna cevap veren katılımcıların sosyal paylaşım ağlarından en çok Facebook isimli sosyal paylaşım ağını kullandıkları anlaşılmıştır.

Balcı ve arkadaşlarının (2013: 19) Selçuk Üniversitesi'nde eğitimlerini sürdüren 440 öğrenci üzerinde yaptıkları araştırmada da üniversite öğrencilerinin en çok ziyaret ettikleri internet siteleri arasında sosyal paylaşım ağları ilk sırada yer almaktadır.

Aydın (2016: 375-380) tarafından Anadolu Üniversitesi uzaktan eğitim öğrencilerinin internet ve sosyal medya kullanımlarını belirlemeye yönelik yapılan bir araştırmada; katılımcıların yüzde 65 gibi bir çoğunluğunun sosyal medyayı arkadaşlarıyla iletişim kurmak amacıyla kullandıkları sonucuna ulaşılmıştır. Bunu, yeni bilgiler edinmek ve araştırma yapmak için kullananlar takip etmiştir. 
Yukarıdaki literatür taraması 1şığında; bu çalışmada da aşağıda sıralanan 6 temel araştırma sorusuna cevap aranmıştır:

- Araştırma Sorusu 1: Katılımcıların kitle iletişim araçlarını takip etme sıklığ1 nedir?

- Araştırma Sorusu 2: Katılımcıların günlük bir oturumda sosyal medya kullanım süresi nedir?

- Araştırma Sorusu 3: Katılımcıların sosyal medya kullanmaya yönelten nedenler nelerdir?

- Araştırma Sorusu 4: Üniversite öğrencilerinin en fazla zaman geçirdiği sosyal paylaşım ağı hangisidir?

- Araştırma Sorusu 5: Katılımcıların cinsiyetine göre sosyal medyaya olan güven düzeyleri nedir? (anlamlı farklılık gösterir mi?)

- Araştırma Sorusu 6: Üniversite öğrencilerinin cinsiyetine göre sosyal medyaya bağımlılık düzeyleri nedir? (anlamlı farklılık gösterir mi?)

\section{YÖNTEM}

$\mathrm{Bu}$ araştırma, genel tarama modeline uygun olarak dizayn edilmiştir. Aynı zamanda çalışmada, bağımlı ve bağımsız değişkenler arasında karşılaştırmalı ilişkisel tarama yapılmıştır.

\subsection{Araştırmanın Uygulanması ve Örneklem Seçimi}

Araştırma evreni, araştırmanın yapıldı̆̆ı zamanı kapsayan dönemde, Konya' da Necmettin Erbakan Üniversitesi'nde eğitim gören ve sosyal medya kullanan öğrencilerden oluşmaktadır. Amaçlı örneklem tekniğinin kullanıldığı araştırmaya toplam 520 kişi dâhil edilmiştir. Araştırmaya konu olan veriler, katılımcılardan yüz yüze görüşmeye dayalı anket tekniğiyle toplanmıştır.

\subsection{Veri Toplama Araçları}

Katılımcların sosyal medya kullanım alışkanlıklarını ölçmek için 4 bölümden toplam 26 sorudan oluşan bir anket formu hazırlanmıştır. Anket formunun ilk bölümünde 5'li Likert tipinde (1=Hiç, 2= Haftada 1-2 Gün, 3= Haftada 3-4 Gün, 4= Haftada 5-6 Gün, 5= Her Gün Düzenli) hazırlanan 6 soruluk bir ölçekte katılımcıların haftalık medya kullanım sıklığı sorgulanmıştır. İkinci bölümdeki açı uçlu soru ile üniversite öğrencilerinin bir oturumda günlük sosyal medya kullanım süreleri sorgulanmıştır. Anketin üçüncü bölümünde ise $5^{\prime}$ li Likert tipinde $(1=$ Hiç Katılmiyorum, 2= Katılmiyorum, 3=Kararsızım, 4=Katılıyorum, 5= Tamamen Katılıyorum) hazırlanan 11 maddelik bir ölçekle katılımcıların sosyal medya kullanım nedenleri öğrenilmeye çalışılmıştır. Araştırmanın dördüncü bölümünde ise katılımcıların sosyal medya bağımlılık düzeyi ile sosyal medyaya olan güven düzeyini ölçmek için de 1 ile 10 arasında 'tablo işaretleme' yöntemi kullanılmıştır. En düşük seviyeye 1, en yüksek seviye 10 olacak şekilde ölçüm yapılmıştır. Anketin son kısmında ise katılımcıların sosyo-demografik özelliklerini belirlemek için hazırlanan sorulardan yer almıştır. 


\subsection{Verilerin Analizi ve Kullanılan Testler}

Alan araştırması 28 Nisan - 20 Mayıs 2017 tarihleri arasında Konya'da Necmettin Erbakan Üniversitesi öğrencileriyle yüz yüze görüşme yoluyla gerçekleştirilmiştir. Elde edilen veriler istatistik paket programı kullanılarak elektronik ortamda işlenmiştir. Belirlenen sorulara cevap bulmak için veriler uygun istatiksel analize tabi tutulmuştur. Araştırmada verilerin analizinde sırasıyla; ankete katılanların demografik özelliklerini ve medya kullanım davranışlarını belirlemek amacıyla frekans analizi kullanılmıştır. Katılımcıların ayrıca cinsiyeti ile sosyal medya kullanım alışkanlıkları arasındaki ilişki Bağımsız Örneklem T-Testi ile ortaya konulmuştur. Günlük bir oturumda sosyal medya kullanım süresi ile sosyal medya bağımlılık düzeyleri arasındaki ilişkinin gücünü ve yönünü tespit etmede de Korelasyon Analizine başvurulmuştur.

\section{BULGULAR VE YORUM}

Bu başlık altında öncelikle katılımcıların bazı özellikleri değerlendirilmekte, daha sonra ise sosyo-demografik özellikleri ile sosyal medya kullanım alışkanlıklarına ilişkin bazı bulgular ortaya konulmaktadır.

\subsection{Katılımcıların Bazı (Sosyo-Demografik) Özellikleri}

Araştırmaya katılanların cinsiyete göre yüzdelik dağılımına bakıldığında katılımcıların yüzde 51,5'ini erkek, yüzde 48,5'i ise kadınlar oluşturmaktadır. Sonuçlar erkekler lehine biraz farklılık görülse de; örneklemin cinsiyet bakımından çok da dengesiz bir dağılıma sahip olmayıp analiz yapılabilecek düzeydedir.

Yaş dağılımının betimleyici istatistikleri incelendiğinde en düşük 17 en yüksek 36 yaşında katılımcılarla görüşüldüğü ortaya çıkmaktadır. Anket sorularını cevaplayanların yaş ortalaması 20,8, dağılımın standart sapması ise 1,94 olarak hesaplanmiştır.

Katılımcıların aylık ortalama yaptıkları harcamaya ilişkin betimleyici istatistik sonuçlarına bakıldığında, en düşük 80 TL, en yüksek 5.000 TL harcama yaptıkları göze çarpmaktadır. Bu sonuçlara göre katılımcıların aylık ortalama yaptıkları harcama 647,3 TL'dir. Aylık ortalama harcamanın standart sapması ise; 453,3'dür.

Sosyal medya araçlarının kullanım tecrübelerine ilişkin soruya cevap veren kullanıcıların yüzdelik dağılımları incelendiğinde; yüzde 10,2'si 1 yıldan az, yüzde 32,3'ü 1-3 yıl arası, yüzde 49,2'si 4-6 yıl, yüzde 8,3'ü 7 yıl ve üzeri sosyal medya araçları kullandıklarını belirtmişlerdir.

Anket uygulanan katılımcılara, sosyal medyaya en çok nereden bağlantı yaptıklarına ilişkin sorulan soruya verilen cevaplar incelendiğinde, yüzde 43,5'i cep telefonu, yüzde 19,4'ü bilgisayar, yüzde 37,1'i ise hem cep telefonu hem de bilgisayar kullanarak sosyal medyaya bağlandıklarını belirtmişlerdir. 


\subsection{Katılımcının Medya Kullanım Alışkanlıkları}

Katılımcıların haftalık ortalama kitle iletişim araçlarının kullanma sıklıklarına ilişkin betimleyici istatistik sonuçlarına bakıldığında, 3.81 aritmetik ortalama ile internet ilk sirada yer almaktadır. İkinci sırada yer alan televizyonun ortalaması $3.68^{\prime}$ dir. Sosyal medya diyenlerin oran 3.64 olurken bunu $2.42^{\prime}$ ile radyo ve 1.59 ile dergi izlemektedir (bkz. Tablo 1).

Tablo 1. Katılımcıların Kitle İletişim Araçları Takip Etme Sıklığının Betimleyici İstatistikleri

\begin{tabular}{|l|r|r|r|}
\hline & $\mathrm{N}$ & \multicolumn{1}{|c|}{ Ortalama } & Standart Sapma \\
\hline İnternet & 500 & 3.81 & .902 \\
\hline Televizyon & 500 & 3.68 & .943 \\
\hline Sosyal Medya & 500 & 3.64 & .927 \\
\hline Gazete & 500 & 2.49 & 1.15 \\
\hline Radyo & 500 & 2.42 & 1.05 \\
\hline Dergi & 500 & 1.59 & .670 \\
\hline
\end{tabular}

Katılımcıların cinsiyetine göre haftalık kitle iletişim araçlarını kullanma sıklığ içerisinde anlamlı farklılaşma; sosyal medya kullanımı ( $\mathrm{t}=--9.554 ; \mathrm{p}<.001)$, radyo dinleme $(\mathrm{t}=-4.371 ; \mathrm{p}<.001)$, internet kullanıminda $(\mathrm{t}=-8.928 ; \mathrm{p}<.001)$ kendini göstermektedir. Katılımcılar arasında kadınlar, erkeklere nazaran haftalık daha sık internet ve sosyal medya kullanırken aynı şekilde daha fazla radyo dinlemektedirler. Katılımcıların cinsiyeti, haftalık televizyon izleme, gazete ve dergi okuma açısından anlamlı farklılaşma meydana getirmemektedir (bkz. Tablo 2).

Tablo 2. Cinsiyete Göre Haftalık Medya Kullanımındaki Farklılık

\begin{tabular}{|l|r|r|r|r|r|}
\hline \multirow{2}{*}{} & \multicolumn{2}{|c|}{ Cinsiyet } & \multirow{2}{*}{$\mathrm{t}$} & \multirow{2}{*}{ df } & \multirow{2}{*}{ Sig. } \\
\cline { 2 - 3 } & Erkek & \multicolumn{1}{|c|}{ Kadın } & & & \\
\hline İnternet & 3.49 & 4.15 & -8.928 & 518 & $\mathbf{. 0 0 0}$ \\
\hline Televizyon & 3.66 & 3.71 & -.557 & 518 & .578 \\
\hline Sosyal Medya & 3.29 & 4.01 & -9.544 & 518 & $\mathbf{. 0 0 0}$ \\
\hline Gazete & 2.50 & 2.49 & .039 & 518 & .969 \\
\hline Radyo & 2.23 & 2.63 & -4.371 & 518 & $\mathbf{. 0 0 0}$ \\
\hline Dergi & 1.58 & 1.60 & -.425 & 518 & .671 \\
\hline
\end{tabular}

\subsection{Katılımcıların Günlük Bir Oturumda Sosyal Medya Kullanma Süresi}

Katılımcıların günlük bir oturumda sosyal medya kullanım sürelerinin betimleyici istatistik sonuçlarına bakıldığında, bir oturumda kullanım süresi en az 3 dakika, en yüksek kullanım süresi 340 dakika olarak bulgulanmıştır. İstatistiğe göre bir oturumda sosyal medya kullanım sürelerinin ortalaması 47.41 'dir. Sosyal medya kullanım süresinin standart sapması ise $47.09^{\prime}$ dur. 
Tablo 3: Günlük Sosyal Medya Kullanım Sürelerinin Betimleyici İstatistikleri

\begin{tabular}{|c|c|c|c|c|c|}
\hline & $\mathrm{N}$ & En Az & En Çok & Ortalama & SD \\
\hline Sosyal medya kullanım süresi & 520 & $3 \mathrm{dk}$. & $340 \mathrm{dk}$ & $47.41 \mathrm{dk}$. & $47.09 \mathrm{dk}$. \\
\hline
\end{tabular}

Katılımcların cinsiyete göre, bir oturumda sosyal medya kullanma süresi anlamlı olarak farklılaşmaktadır ( $\mathrm{t}=-3.090 ; \mathrm{p}<.01)$. Araştırmaya katılanların cinsiyetine göre kadınlar $(\bar{x}=53.94)$, erkeklere $(\bar{x}=41.27)$ oranla bir oturumda daha uzun süre sosyal medya kullanmaktadır (bkz. Tablo 4).

Tablo 4. Cinsiyete Göre Günlük Bir Oturumda Sosyal Medya Kullanma Süresindeki Farklilık

\begin{tabular}{|l|c|r|r|c|c|c|}
\hline \multicolumn{1}{|c|}{ CंNSİYET } & $\mathrm{N}$ & Ortalama & Std. Sapma & $\mathrm{t}$ & $\mathrm{df}$ & Sig. \\
\cline { 1 - 5 } Erkek & 268 & 41.27 & 54.38 & -3.090 & 518 & $\mathbf{. 0 0 2}$ \\
\hline Kadın & 252 & 53.94 & 36.83 & 518 \\
\hline
\end{tabular}

\subsection{Katılımciların Sosyal Medya Kullanma Nedenleri}

Tablo 5'de de görüldüğü gibi; katılımcıların sosyal medya kullanım nedenleriyle ilgili soruya eğlenmek ve rahatlamak için 4,10 aritmetik ortalamasıyla en yüksek öneme sahiptir. İkinci sırada; 4,01 aritmetik ortalamasıyla arkadaşlarımla iletişimde bulunmak, üçüncü sırada, 3,53 aritmetik ortalamasıyla çeşitli konularda bilgi sahibi olmak için şıkkı yer almaktadır. Araştırmaya katılanların sosyal medya kullanım nedenleri arasında en az öneme sahip madde ise; 2,50 aritmetik ortalamasıyla 'kişisel sunum ve profil bilgilerimi paylaşmak' maddesi yer alırken, bunu 2,54 aritmetik ortalaması ile 'benim için alışkanlık haline geldi' ifadesi izlemektedir (bkz. Tablo 5).

Tablo 5. Sosyal Medya Kullanma Nedenlerinin Betimleyici İstatistikleri

\begin{tabular}{|l|c|c|c|c|}
\hline & En Az & En Çok & Ortalama & SD \\
\hline Eğlenmek ve rahatlamak İçin & 1 & 5 & 4.10 & 1.06 \\
\hline Arkadaşlarımla iletişimde bulunmak & 1 & 5 & 4.01 & .984 \\
\hline Çeşitli konularda bilgi sahibi olmak için & 1 & 5 & 3.53 & 1.23 \\
\hline Boş zamanlarımı değerlendirmek için & 1 & 5 & 3.37 & 1.27 \\
\hline Mesaj göndermek ya da mesaj almak & 1 & 5 & 3.30 & 1.36 \\
\hline Tanıdıkların duvarına yazmak/ yazdıklarını okumak & 1 & 5 & 3.08 & 1.21 \\
\hline $\begin{array}{l}\text { Tanıdıklarımın fotoğraflarına bakmak/ fotoğraf } \\
\text { yüklemek }\end{array}$ & 1 & 5 & 3.07 & 1.27 \\
\hline İnsanların İletişim Bilgilerine Ulaşmak İçin & 1 & 5 & 2.87 & 1.22 \\
\hline İnsanları daha iyi tanımak için & 1 & 5 & 2.64 & 1.16 \\
\hline Benim için alışkanlık haline geldi & 1 & 5 & 2.54 & 1.28 \\
\hline Kişisel sunum ve profil bilgilerini paylaşmak için & 1 & 5 & 2.50 & 1.23 \\
\hline
\end{tabular}

Araştırmada, katılımcıların cinsiyeti ile sosyal medya kullanım nedenleri arasında anlamlı bir farklılaşma olup olmadığını tespit etmek amacıyla bağımsız örneklem T- testi uygulanmıştır. Analiz sonuçlarına göre; boş zamanları değerlendirmek için şıkkı ile cinsiyet arasında anlamlı bir farklılaşma tespit edilirken 
$(\mathrm{t}=-5.170 ; \mathrm{p}<.001)$, tanıdıklarımın fotoğraflarına bakmak yada fotoğraf yüklemek için $(\mathrm{t}=3.316 ; \mathrm{p}<.01)$, tanıdıklarımın duvarına yazmak ya da duvarıma yazılanları okumak için ( $\mathrm{t}=3.893 ; \mathrm{p}<.001)$, kişisel sunum ve profil bilgilerini paylaşmak için $(\mathrm{t}=3.405 ; \mathrm{p}<$ $.01)$, benim için alışkanlık haline geldi $(\mathrm{t}=11.538 ; \mathrm{p}<.001)$, insanları daha iyi tanımak için $(\mathrm{t}=2.800 ; \mathrm{p}<$.01) şıklarıyla cinsiyet arasında da anlamlı bir farklılaşma tespit edilmiştir. Betimleyici istatistik sonuçları incelendiğinde erkekler, kadınlara göre boş zamanlarını değerlendirmek için, tanıdıklarımın duvarına yazmak ya da yazdıklarını okumak, tanıdıklarımın fotoğraflarına bakmak/ fotoğraf yüklemek, insanları daha iyi tanımak, kişisel sunum ve profil bilgilerini paylaşmak için daha fazla sosyal medya kullanmaktadır. Buna karşılık mesaj göndermek ya da mesaj almak, insanların iletişim bilgilerine ulaşmak ve boş zamanlarını değerlendirmek için kadınlar erkeklere oranla daha fazla sosyal medya kullanmaktadır (Tablo 6).

Tablo 6. Katılımcıların Cinsiyetine Göre Sosyal Medya Kullanma Nedenlerindeki Farklilık

\begin{tabular}{|l|r|r|r|r|r|}
\hline \multirow{2}{*}{} & \multicolumn{2}{|c|}{$\begin{array}{c}\text { Aritmetik } \\
\text { Ortalamalar }\end{array}$} & \multicolumn{1}{c|}{$\mathrm{t}$} & \multicolumn{1}{c|}{ da } & \multicolumn{1}{c|}{ Sig. } \\
\cline { 2 - 4 } & Erkek & \multicolumn{1}{|c|}{ Kadın } & & & \\
\hline Eğlenmek ve Rahatlamak İçin & 4.08 & 4.13 & -.606 & 518 & .545 \\
\hline Arkadaşlarımla iletişimde bulunmak & 4.02 & 4.00 & .210 & 518 & .833 \\
\hline Çeşitli konularda bilgi sahibi olmak & 3.52 & 3.53 & -.091 & 518 & .928 \\
\hline Boş zamanlarımı değerlendirmek için & 3.10 & 3.67 & -5.170 & 518 & $\mathbf{. 0 0 0}$ \\
\hline Mesaj göndermek ya da mesaj almak & 3.26 & 3.34 & -.670 & 518 & .503 \\
\hline $\begin{array}{l}\text { Tanıdıkların duvarına yazmak/ } \\
\text { yazdıklarını okumak }\end{array}$ & 3.28 & 2.87 & 3.893 & 518 & $\mathbf{. 0 0 0}$ \\
\hline $\begin{array}{l}\text { Tanıdıklarımın fotoğraflarına bakmak/ } \\
\text { fotoğraf yüklemek }\end{array}$ & 3.25 & 2.88 & 3.316 & 518 & $\mathbf{. 0 0 1}$ \\
\hline $\begin{array}{l}\text { İnsanların İletişim Bilgilerine Ulaşmak } \\
\text { İçin }\end{array}$ & 2.68 & 3.08 & -3.760 & 518 & $\mathbf{. 0 0 0}$ \\
\hline İnsanları daha iyi tanımak için & 2.77 & 2.49 & 2.800 & 518 & $\mathbf{. 0 0 5}$ \\
\hline Benim için alışkanlık haline geldi & 1.98 & 3.14 & -11.538 & 518 & $\mathbf{. 0 0 0}$ \\
\hline $\begin{array}{l}\text { Kişisel sunum ve profil bilgilerini } \\
\text { paylaşmak için }\end{array}$ & 2.68 & 2.31 & 3.405 & 518 & $\mathbf{. 0 0 1}$ \\
\hline
\end{tabular}

\subsection{Katılımcıların En Fazla Zaman Geçirdikleri Sosyal Paylaşım Ağları}

Katılımcılara, eğer birden fazla sosyal ağda profilleri varsa en fazla hangisinde zaman harcadıkları sorulmuştur. Araştırmaya katılanların nerdeyse yarısı (yüzde 47,9) en fazla Facebook' da zaman harcadıklarını belirtmişlerdir. 
Tablo 7. Katılımcıların En Fazla Zaman Harcadıkları Sosyal Paylaşım Ağlarının Betimleyici İstatistikleri

\begin{tabular}{|l|c|c|}
\hline & Frekans & Yüzde \\
\hline Facebook & 249 & $\% 47.9$ \\
\hline Twitter & 145 & $\% 27.9$ \\
\hline Instagram & 96 & $\% 18.5$ \\
\hline Diğer & 30 & $\% 5.8$ \\
\hline Toplam & $\mathbf{5 2 0}$ & $\mathbf{\% 1 0 0 . 0}$ \\
\hline
\end{tabular}

Tablo 7'de de görüldüğü gibi katılımcıların yüzde 47,9'u en fazla zaman geçirdiği sosyal medya ağının Facebook olduğunu belirtirmiştir. Bunu sırasıyla; Twitter ve Instagram izlemektedir.

\subsection{Katılımcıların Sosyal Medyaya Güven Düzeyi}

Katılımcıların sosyal medyaya güven düzeyini belirlemek için 1 ile 10 arasında puan vermelerine yönelik bir skala ( $1=$ hiç güvenmem, $10=$ çok güvenirim) oluşturulmuştur. 520 kişinin verdiği cevaplar doğrultusunda yapılan betimleyici istatistik analizi sonuçları, katılımcıların orta düzeye yakın $(\bar{x}=4.70)$ sosyal medyaya güven duydukları sonucuna ulaşmıştır (bkz. Tablo 8).

Tablo 8. Sosyal Medyaya Güven Düzeyiniz Betimleyici İstatistikleri

\begin{tabular}{|l|c|c|c|c|c|}
\hline & Kişi Sayısı & En Az & En Yüksek & Ortalama & SD \\
\hline $\begin{array}{l}\text { Sosyal Medyaya } \\
\text { Güven Düzeyi }\end{array}$ & 520 & 1 & 10 & 4.70 & 2.40 \\
\hline
\end{tabular}

Tablo 9'da da görüldüğü gibi katılımcıların cinsiyetine göre sosyal medyaya güven düzeyi arasında anlamlı farklılık göstermektedir $(\mathrm{t}=-12.448 ; \mathrm{df}=518 ; \mathrm{p}<.001)$. Araştırmaya katılanların cinsiyetine göre sosyal medyaya güven düzeyi erkeklerde 3,59 ortalamaya sahip iken, bu durum kadınlarda ise 5,89'dur (bkz. Tablo 9).

Tablo 9. Cinsiyete Göre Sosyal Medyaya Güven Düzeyi

\begin{tabular}{|c|c|c|c|c|c|c|}
\hline CINSIYET & $\mathrm{N}$ & Ortalama & Std. Sapma & $\mathrm{t}$ & $\mathrm{df}$ & Sig. \\
\cline { 1 - 4 } Erkek & 268 & 3.59 & 2.12 & -12.448 & 518 & $\mathbf{. 0 0 0}$ \\
\hline Kadın & 252 & 5.89 & 2.09 & & \\
\hline
\end{tabular}

Araştırmada ayrıca günlük sosyal medya kullanım süresi ile sosyal medyaya olan güven düzeyi arasındaki ilişkinin yönünü ve gücünü belirlemek için yararlanılan korelasyon analizi sonuçları incelendiğinde, iki değişken arasında pozitif yönde zayıf anlamlı ilişki bulunmaktadır $(r=.279 ; \quad \mathrm{p}<.001)$. Buna göre günlük sosyal medya kullanım süresi arttıkça; sosyal medyaya güven düzeyinde de bir artış görülmektedir (bkz. Tablo 10). 
Tablo 10. Günlük Sosyal Medya Kullanma Süresi İle Sosyal Medyaya Güven Arasındaki İlişki

\begin{tabular}{|l|r|}
\hline & \multicolumn{2}{|c|}{ Sosyal medyaya güven düzeyi } \\
\hline Günlük sosyal medya kullanım süresi & $.279^{* *}$ \\
\hline $\mathrm{N}$ & \multicolumn{2}{|c|}{520} \\
\hline \multicolumn{2}{|c|}{ Not: $^{* *} \mathrm{p}<.001$} \\
\hline
\end{tabular}

\subsection{Katılımcıların Sosyal Medya Bağımlılık Düzeyi}

Katılımcıların sosyal medyaya bağımlılık düzeylerini belirlemek üzere 1 ile 10 arasında puan vermelerine yönelik hazırlanan bir skaladan (1= Hiç Bağımlı Değilim, $10=$ Oldukça Bağımlıyım) yararlanılmıştır. 520 kişinin verdiği cevaplar doğrultusunda yapılan betimleyici istatistik analizi sonuçları; katılımcıların orta düzeye $(\bar{x}=4.87)$ yakın oranda bağımlılı̆̆a sahip oldukları ortaya koymaktadır.

Tablo 11. Katılımcıların Sosyal Medyaya Bağımlılık Düzeyinin Betimleyici İstatistikleri

\begin{tabular}{|l|c|c|c|c|c|}
\hline & Kişi Sayısı & En Az & En Yüksek & Ortalama & SD \\
\hline $\begin{array}{l}\text { Sosyal Medyaya bağımlılık } \\
\text { düzeyi }\end{array}$ & 520 & 1 & 10 & 4.87 & 2.39 \\
\hline
\end{tabular}

Araştırmaya katılanların cinsiyetine göre sosyal medya bağımlılık düzeyleri anlamlı farklılık taşımaktadır $(\mathrm{t}=-8.304 ; \mathrm{p}<.001)$. Araştırmada kadınların 5,27 aritmetik ortalama değeriyle, sosyal medya bağımlılık düzeyleri erkeklere $((\bar{x}=4.08)$ göre daha yüksektir (bkz. Tablo 12).

Tablo 12. Katılımcıların Cinsiyete Göre Sosyal Medya Bağımlılığı Düzeyindeki Farklılık

\begin{tabular}{|l|c|c|c|c|c|c|}
\hline \multicolumn{1}{|c|}{ CINSIYET } & $\mathrm{N}$ & Ortalama & $\mathrm{SD}$ & $\mathrm{t}$ & $\mathrm{df}$ & Sig. \\
\hline Erkek & 268 & 4.08 & 2.49 & \multirow{2}{*}{-8.304} & 518 & $\mathbf{. 0 0 0}$ \\
\cline { 1 - 5 } Kadın & 252 & 5.72 & 1.96 & & & \\
\hline
\end{tabular}

Araştırmada günlük bir oturumda sosyal medya kullanım süresi ile sosyal medya bağımlılığı düzeyi arasındaki ilişkinin yönünü ve gücünü belirlemek için yapılan korelasyon analizi sonuçları incelendiğinde; iki değişken arasında pozitif yönde zayıf düzeyde anlamlı bir ilişki bulunduğu dikkat çekmektedir ( $r=.247$; $\mathrm{p}<.001)$. Buna göre araştırmaya katılanların günlük sosyal medya kullanım süresi arttıkça sosyal medyaya bağımlılık düzeyinde de bir artış yaşanmaktadır (bkz. Tablo 13). 
Tablo 13. Bir Oturumda Günlük Sosyal Medya Kulanma Süresi İle Sosyal Medya Bağımlılığı Arasındaki İlişki

\begin{tabular}{|l|rr|}
\hline & \multicolumn{2}{|c|}{ Sosyal medyaya bağımlılık düzeyi } \\
\hline $\begin{array}{l}\text { Günlük bir oturumda sosyal medya } \\
\text { kullanım süresi }\end{array}$ & & $.247^{* *}$ \\
\hline $\mathrm{N}$ & & 520 \\
\hline \multicolumn{2}{|c|}{ Not: $^{* *} \mathrm{p}<.00$} \\
\hline
\end{tabular}

\section{SONUÇ}

Dünyada ve ülkemizde internet sisteminin gelişmesi, yaygınlaşması ve kullanımının giderek artması, internetin yaşamamızda daha çok yer aldığı ve almaya artarak devam edeceği anlamına gelmektedir. İnternetin insan yaşamını birçok açıdan kolaylaştırdığı inkâr edilemez. Ancak yine de kontrollü ve bilinçli kullanılması elzemdir. Özellikle doğdukları andan itibaren internet hayatlarında var olan yeni nesil, internet bağımlılığıyla baş başadır. İnternetin ve sunduğu içerik ile imkânların doğru ve bilinçli kullanılması önemlidir. İnternetin kullanılmaya başlanmasıyla birlikte sunduğu içerikler yaşamımızın vazgeçilmezleri arasına yer almaya başlamıştır. Bunlardan biri de sosyal medya diye adlandırılan mecralardır. Özellikle yeni neslin ilgi gösterdiği ve yaşamlarının vazgeçilmez bir parçası haline gelen sosyal medya gençler arasında sıklıkla kullanılmaktadır. Bu yüzden sosyal medyanın insanlar üzerindeki etkileri hem önem kazanmış hem de araştırılmak istenmiştir. Sosyal medyanın etkilerine yönelik araştırmalar çokça yapılmaktadır.

$\mathrm{Bu}$ çalışma da bu etkileri ölçmeye yönelik hazırlanmıştır. Araştırma kapsamında üniversite öğrencilerinin sosyal medya kullanım alışkanlıkları mercek altına alınmış; araştırmada katılımcıların en sık kullandıkları iletişim aracı olarak internet ilk sirada yer alırken bunu televizyon ve sosyal medya takip etmektedir. Cinsiyete göre kadınlar, erkeklere nazaran haftalık daha sık internet, sosyal medya kullanırken yine kadınlar erkeklere oranla daha sık radyo dinlemektedir.

Yine araştırmaya katılan üniversite öğrencilerinin günlük bir oturumda ortalama sosyal medya kullanım süresinin 47,41 dakika olduğu sonucuna varılmıştır. Araştırmada kadınların bir oturumda sosyal medya kullanım sürelerinin erkeklere oranla daha yüksek olduğu sonucuna varılmıştır. Araştırmaya katılanların, sosyal medyaya en çok cep telefonundan bağlandıkları sonucuna ulaşılmıştır. Özellikle son yıllarda akıllı telefonların yaygınlaşmasından dolayı böyle bir sonuç çıkması normaldir.

Necmettin Erbakan Üniversitesi örneğinde yürütülen bu saha çalışmasında aynı zamanda öğrencilerin sosyal medya bağımlılık düzeyleri de mercek altına alınmıştır. Betimletici istatistik sonuçları; katılımcıların orta düzeye yakın oranda sosyal medya bağımlısı olduğu görülmektedir. Araştırmada kadınların bağımlılık düzeyleri erkeklere göre daha yüksektir. Katılımcıların günlük sosyal medya kullanım süresi arttıkça, bağımlılık düzeylerinde de bir artış yaşanmaktadır. 
Katılımcıların sosyal medya kullanım nedenleri arasında ise; eğlenme ve rahatlama, arkadaşlarla iletişimde bulunma, çeşitli konularda bilgi sahibi olma ve boş zamanları değerlendirme şıkları ilk sıralarda yer almaktadır.

Araştırmada elde edilen bir başka sonuç ise; katılımcıların sosyal medyaya orta düzeyde güven duyduklarıdır. Cinsiyet açısından kadınlar sosyal medyaya güven düzeyi erkeklere oranla daha yüksektir. Katılımcıların günlük sosyal medyaya kullanım süresi artıkça, sosyal medyaya güven düzeyinde de bir artış görülmektedir.

Sonuç olarak üniversite öğrencilerinin sosyal medya kullanım alışkanlıklarını ortaya koyması bakımından yürütülen bu çalışma, gelecekte farklı bölgelerde ve farklı örneklem üzerinde yürütülecek araştırmalarla hem literatürün genişlemesi sağlanabilir hem de farklı araştırmalar arasında karşılaştırmalar yapmak daha olanaklı hale gelebilir.

\section{KAYNAKÇA}

Al-Deen,N.S.H ve Hendricks, A.J.(2012). “Social Media Usage and Impact", USA: Lexington Books.

Aydın, E,İ.(2016). “Üniversite Öğrencilerinin Sosyal Medya Kullanımları Üzerine Bir Araştırma: Anadolu Üniversitesi Örneği", (35): 373-386.

Balc1, Ş., ve Koçak, M. C. (2017). "The Relations between Social Media Usage and Life Satisfaction: A Survey on University Students". The First International Conference on New Trends in Communicaiton, İstanbul, 4-5 May 2017, 34-45.

Balc1, Ş. Ve Diğerleri, (2013). " Üniversite Öğrencileri Arasında İnternet Kullanım Örüntüleri ", Selçuk İletişim, 7 (4), , 5-22,

Boyd, D. M. ve Ellison, N. B., (2007). Social Network Sites: Definition, History, and Scholarship, Journal of Computer-Metiated Communication, Vol.13, No.1.

Çalışır, G. (2015). “Kişilerarası İletişimde Kullanılan Bir Araç Olarak Sosyal Medya: Gümüşhane Üniversitesi İletişim Fakültesi Öğrencilerine Yönelik Bir Çalışma", NWSA-Humanities E-Journal of New World Sciences Academy, ISSN: 1306-3111 /1308-7320, http://dx.doi.org/10.12739/NWSA.2015.10.3.4C0197, 10 (3), 115-144.

Englander, F., Terregrossa, R. A., Wang, Z. (2010). “Internet Use Among College Student: too or toy?", Educational Review, 62(1), 85-96.

Fouts,J.(2009). "Social Media Success: Practical Advice and Real World Examples for Social, California: Happyabout". İnfo.

Hazar, M. (2011). “Sosyal Medya Bağımlılı̆̆ı- Bir Alan Çalışması", Gazi Üniversitesi İletişim Fakültesi İletişim Kuram ve Araştırma Dergisi, Sayı 32.

Kirtiş, K. A., Karahan, F. (2011). “To be or not to be in Social Media Arena as the Most Costefficient Marketing Strategy after the Global Recession." Procedia Social and Behavioral Sciences, 24, 260-268.

Küçükali, A.(2016). “Üniversite Öğrencilerinin Sosyal Medya Kullanımı: Atatürk Üniversitesi Örneği", Bartın Üniversitesi İ.̇̇.B.F. Dergisi, cilt:7, Sayı:13 
Lüsted, A. M. (2011). "Social Networking: Myspace, Facebook and Twitter", America: ABDO Publishing Campany.

Neuman, M. Hogan, D. and MacDonaill, C. (2005). "Semantic Social Network Portal for Collaborative Online Communities", Journal of European Industrial Training, Vol:29, No:6.

Obee,J.(2012). The Ultimate Teen Guide, Toronto: The Scarecrow Press.

Onat, F., Alikılıç, Ö. A. (2008). “Sosyal A $\breve{g}$ Sitelerinin Reklam ve Halkla İlişkiler Ortamları Olarak Değerlendirilmesi", Journal of Yaşar University, 3(9), 1111-1143.

Özdemir, S. S., ve Diğerleri (2014) “Sosyal Medya Kavramı Ve Sosyal A Online Reklam Uygulamalarının İncelenmesi", Electronic Journal of Vocational Colleges-December/Aralık 2014

Ryan,K.P.(2011)."Social Networking", New York: Rosen Publishing.

Tektaş, N.(2014). “Üniversite Öğrencilerinin Sosyal Ağları Kullanımlarına Yönelik Bir Araştırma", Journal of History School(JOHS), 7(17): 851-870.

Van Dijck, j.(2013). "The Culture of Connectivity: A Criticial History of Social Media”, Oxford: Oxford Üniversity Press.

Vural, Z. B.A. \& Bat M., (2010). “Yeni Bir İletişim Ortamı Olarak Sosyal Medya:Ege Üniversitesi İletişim Fakültesine Yönelik Bir Araştırma", Journal of Yaşar University, 20(5), 33483382. 